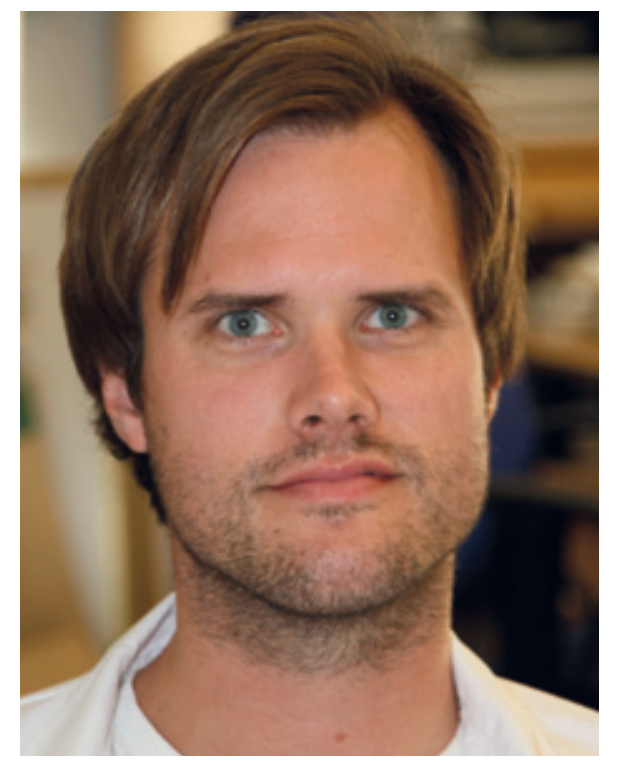

\section{Glukosamin har ingen effekt mot korsryggssmerter}

\author{
Glukosaminsulfat brukes ofte ved korsryggssmerter, men det \\ er ikke bedre enn placebo for å redusere smerte og funksjonssvikt, \\ viser ny norsk studie.
}

Korsryggssmerter er en av de vanligste plagene i muskel- og skjelettapparatet. Hos de fleste pasienter er den eksakte årsaken og smertemekanismen ukjent, og en lang rekke behandlingsmetoder benyttes. Tidligere studier har vist at glukosamin kan ha lindrende effekt ved hofte- og kneartrose, men slik behandling er omdiskutert. Nå har norske forskere undersøkt effekten av medikamentet ved langvarige korsryggsplager med degenerative forandringer (1).

Hensikten med studien var å undersøke om glukosamin var bedre enn placebo $\mathrm{i}$ å redusere smerte og bedre funksjon og livskvalitet hos korsryggspasienter gjennom et dobbelblindet, randomisert, placebokontrollert forsøk. Studien omfattet 250 pasienter over 25 år henvist fra primærhelsetjenesten (fastlege, kiropraktor og fysioterapeut) med korsryggssmerter som hovedplage i minst seks måneder og med påvist synlige lumbale degenerasjonsfunn ved MR.

Pasientene ble tilfeldig fordelt til to grupper som enten fikk daglig glukosaminsulfat $1500 \mathrm{mg}$ peroralt eller et placebopreparat. Hovedeffektmål var funksjon i dagliglivet målt ved Roland Morris Disability Questionnaire (RMDQ). Sekundære effektmål var bl.a. korsryggssmerte i hvile og aktivitet, og livskvalitet.

- Etter seks måneder og ett år var det ingen signifikant forskjell i smerte og funksjon mellom pasientene som fikk glukosamin og de som fikk placebo. Det var heller ikke signifikante forskjeller mellom gruppene når det gjaldt de sekun-
Philip Wilkens. Foto Beate Ørbeck

\section{Ordforklaringer}

Glukosamin er et svovelholdig aminomonosakkarid som inngår i proteoglykanskjelettet i leddbrusk. Det er i flere land klassifisert som helsekostprodukt, men i Norge er midlet reseptbelagt. Godkjent indikasjon er mild til moderat artrose.

\section{Roland Morris Disability Questionnaire} (RMDQ): Standardisert og validert skjema for kartlegging av korsryggspasienters funksjonsevne i dagliglivet. Det ble utviklet tidlig på 1980-tallet, og kan brukes både for akutte og kroniske ryggpasienter. RMDQ består av 24 spørsmål hvorav 20 kartlegger evne til å utføre daglige aktiviteter/funksjoner, ett smerte, ett søvn og to kartlegger mentale funksjoner. På skalaen $0-24$ er 0 = ingen funksjonsbegrensninger og 24 = maksimal funksjonsbegrensning. Utfylling av skjema foregår ved at pasienten krysser av for om utsagnet angår dem eller ikke (ja/nei). Skåring foregår ved at antall ja summeres. Skjemaet egner seg både til forskning og klinisk bruk.

EQ-5D (EuroQol-5 Dimensions): Standardisert og validert skjema for måling av livskvalitet i ulike pasientgrupper. Skjemaet består av fem spørsmål som kartlegger følgende områder: gange, personlig stell, dagligdagse gjøremål, smerte/ubehag og angst/depresjon, i tillegg til en $100 \mathrm{~mm}$ VAS-skala hvor pasienten skal angi sin egen helsetilstand. Skjemaet er raskt for pasienten å fylle ut og er tilrettelagt for utregning av kvalitetsjusterte leveår, noe som gjør at det kan benyttes i helseøkonomiske analyser.

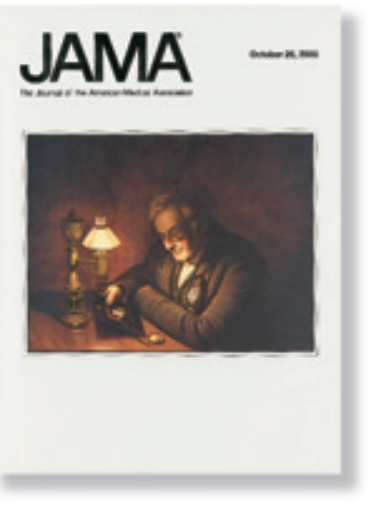

Artikkelen ble publisert 7.7. 2010 i JAMA (www.jama.com), som regnes som en av de «fem store» innen medisinsk publisering ved siden av New England Journal of Medicine, BMJ, Annals of Internal Medicine og The Lancet

Litteratur

1. Wilkens P, Scheel IB, Grundnes 0 et al. Effect of glucosamine on pain-related disability in patients with chronic low back pain and degenerative lumbar osteoarthritis: a randomized controlled trial. JAMA 2010; 304: 45-52.

2. Avins AL. Glucosamine and the ongoing enigma of chronic low back pain. JAMA 2010; 304: 93-4. 